\title{
A Comparison of Vegetative Climate of Artemisia Sieberi Besser and Artemisia Aucheri Boiss in Iran
}

Morteza Khodagholi ( $\sim$ m_khodagholi@yahoo.com)

Research Institute of Forests and Rangelands https://orcid.org/0000-0001-7969-6386

Razieh saboohi

Isfahan Agricultyre and natural resources research and education center

Ehasan Zandi Esfahani

Research Institute of Forests and Rangelands

\section{Research Article}

Keywords: Climatic factors, Artemisia sieberi, Artemisia aucheri, factor analysis, Iran

Posted Date: March 9th, 2021

DOI: https://doi.org/10.21203/rs.3.rs-167707/v1

License: (c) (1) This work is licensed under a Creative Commons Attribution 4.0 International License. Read Full License 


\section{Abstract}

The relationship between plant species and climatic factors has always been a fundamental issue in plant ecology, and the use of multivariate statistical methods can be effective in revealing the relationship between climatic factors and plant species distribution. Therefore, in this study, climatic factors affecting the distribution of Artemisia sieberi and Artemisia aucheri, widely distributed in Iran, were investigated. For this purpose, 117 climatic factors were used, and to reduce the number of factors and determine the most important effective ones, a factor analysis was used by principal component analysis. The results showed that six factors including heating temperature, spring and summer precipitation, wind, autumnwinter precipitation, and dusty and cloudiness days explained $37.32 \%, 22.54 \%, 7.18 \%, 6.6 \%, 4.22 \%$, and $4.15 \%$ of data variation, respectively. Together these seven factors account for $82 \%$ of data variation. The autumn-winter precipitation and heating temperature had the greatest impact on the presence of Artemisia sieberi and Artemisia aucheri, respectively, so that the autumn-winter precipitation was negative in areas where Ar.sieberi is observed. The heating temperature factor is negative in areas where Ar.aucheri is present, while it is positive in areas lacking Ar.aucheri. The study of the effect of environmental factors on Artemisia species distribution is very important in planning and management of natural resources, and Artemisia is one of the most important plants in the country's rangelands; therefore, the results of this research can be used for practical planning, management and reclamation of these rangelands.

\section{Introduction}

Iranian rangelands with an area of 90 million hectares cover the widest area of the country (about $54 \%$ ), more than $70 \%$ of which are located in arid and semi-arid regions. The general land-use of these lands in the country is rangeland, and overgrazing in these regions has often led to changes in the quantity and quality of vegetation and soil, increasing barren lands, and desertification expansion (Azarnivand et al., 2009). Proper management and exploitation of rangelands requires identifying the characteristics of the key species and determining the factors affecting their distribution (Azarnivand et al., 2003).

A large part of Iran, especially mountainous areas, is covered by shrubs, and areas with this type of vegetation are among the important rangeland (Mozaffarian, 1989). Artemisia L. is the largest genus of the Anthemideae tribe and one of the largest genera in the Asteraceae family. Globally, the number of species of this genus is estimated between 200 to 450 species (Jalili, 2015). In Iran, this genus has 34 known species, which is one of the most significant and important plant species in the flora of Iran in terms of distribution. Different species of this genus in Iran have distributed from the lowest points of the Caspian Sea to altitudes of $\mathbf{4 0 0 0}$ meters above sea level. In many areas, some species, including Artemisia sieberi and Artemisia aucheri, are considered the most important forage plants of rangelands. In addition to the forage value, industrial and pharmaceutical applications of different species have caused them to receive special attention (Rashtian and Karimian., 2014).

According to Azarnivand (2003) and Jafari et al., (2003), Artemisia sieberi is considered as the most important species of this genus in Iran because it is the dominant vegetation cover of the Irano-Turanian region and steppe regions in Iran. This species is highly resistant to harsh environmental conditions due to its prominent features and therefore plays an important role in the stability and survival of vegetation. Also Artemisia aucheri Boiss is very valuable in arid and semi-arid regions in terms of environmental protection, especially prevention of soil erosion and providing forage for livestock and wildlife (Mozaffarian, 1989).

Extent Habitats of Artemisia sieberi and Artemisia aucheri and their different characteristics in Iran. It has attracted the attention of various researchers.

Akbar pourYasaghi (1995) studied the ecological characteristics of $A$. aucheri in the Gorgan and Dasht region and concluded that the minimum altitude of the habitat of this species was 900 meters in the Khosh Yilagh region and its maximum altitude was 2700 meters in Chaharbagh region. The highest density of this species was in the altitude range of 2000 meters. 
Azarnivand et al., (2003) investigated the effect of soil properties and altitude changes on the distribution of $A$. sieberi and $A$. aucheri in Vardavar, Garmsar, and Semnan rangelands, and after studying vegetation, soil, and topography data from different habitats, they found that organic matter, soil nitrogen, and gypsum, and altitude were the most important factors influencing the distribution of these two species in the study areas.

Climate is a general condition of the prevailing weather conditions of a particular place based on long-term statistics (Bailey. Robert, 1991). There are different methods for climate zoning, most of which are based on temperature and rainfall, but sometimes zoning is based on important non-climatic factors such as vegetation. Vegetation plays an important role in climatic zoning. In fact, it can be used as a set of different climatic and topographic patterns; therefore, it is possible to use the adaptation of vegetation and climate maps to identify bioclimatic zones (Chamberlain and Matthews, 1970). In recent years, valuable studies have been conducted on vegetative climate and zoning, which can be referred to the studies of Saboohi and Barani (2015), Khodagholi et al. (2015), Saboohi and Khodagholi (2013), Pakzad et al. 1392), Fatemi et al. (2012), Lashni et al. (2011), Taste et al., (2008), and Khodagholi et al. (2007). In a study conducted by Saboohi and Barani (2016), the cooling-humidity temperature, rain-thunder, cloudiness, and wind were reported as the factors affecting the distribution of Astragalus gossypinus in Isfahan province, respectively accounting for $39.05 \%, 32.77 \%, 11.44 \%$, and $8.63 \%$ (totally $91.88 \%$ ) of variation in initial variables of Isfahan's vegetative climate. Khodagholi et al. (2015) studied the climatic characteristics of Quercus brantii in Chaharmahal and Bakhtiari province. The results showed that precipitation, heating temperature, and wind, with $28.79 \%, 20.13 \%$, and $4.71 \%$, respectively, were the three factors affecting the distribution of this species. For climatic zoning of Sistan and Baluchestan province, Saliqeh et al. (2008) used 20 climatic variables, and with the methods of factor analysis and climatic clustering of the province came to the conclusion that the climate of the province is made up of five factors including rainfall, temperature, radiation, wind, and thunder. Globally, Pineda-Martinez et al. (2007) zoned the bioclimatic regions of central and northeastern Mexico using factor analysis. Zhou et al. (2009) zoned the East Murrumbidgee Irrigation Area (MIA) using factor analysis and clustering. They used long-term climate data to study climate variability. The results show two classifications. Yunus (2011) used factor analysis and clustering method for Malaysian bioclimatic classification, and the results showed a very good effect of these methods on this classification.

Since Artemisia rangelands are affected by destructive human activities and livestock grazing, they are among the ecosystems that need to be conserved. Therefore, the first step to prevent degradation is to identify vegetation and studying plant communities and the factors affecting them. Using this information, proper management methods to maintain and improve these important rangelands of the country are reviewed, and correct conservation decisions are made. For this purpose, the climatic characteristics of $A$. sieberi and $A$. aucheri were investigated.

\section{The study area}

Iran with an area of 1.648000 square kilometers is located between latitudes $25^{\circ} 3^{\prime}$ to $39^{\circ} 47^{\prime} \mathrm{N}$, and longitudes $44^{\circ} 5^{\prime}$ to $63^{\circ}$ $18^{\prime} \mathrm{E}$ in southwest Asia (Razei et al., 2005). Therefore, in terms of latitude, its southern parts are located in the tropics, and its northern parts are in the subtropical regions. Iran has different climates due to the 15-degree difference in latitude between southernmost and northernmost points and also due to the topography and elevations.

Regardless of these two factors, air masses colliding with each other from different lands on the plateau of Iran are considered as important determinants of Iran's climate. Adjacent to the Sea of Oman and the Persian Gulf on the one hand and the influence of the Mediterranean Sea on the other hand, the arid desert of Saudi Arabia and Africa, and the Great Siberian Plain in the northeast are profoundly effective in the type of air masses reaching Iran (Alizadeh et al., 2012). As a result, Iran has special characteristics geographically and possesses a very variable climate. Iran is a relatively high land so that its average altitude is more than 1000 meters above sea level (Faraji., 2005).

The average annual precipitation of the whole country is about $252 \mathrm{~mm}$, and the maximum amount in the Caspian Sea and the sloping areas of the Alborz and Zagros mountains is 1800 and $400 \mathrm{~mm}$, respectively. Moving towards the interior areas in 
the center and east, the amount of precipitation even reaches less than $100 \mathrm{~mm}$ per year, depending on the location (Alizadeh et al., 2012).

\section{Materials And Methods}

The totality of the climate of each place is achieved through the use of all climatic elements. Therefore, the data of 117 climatic variables in 164 synoptic meteorological stations of the country (Fig. 1) were selected in monthly and annual intervals (Table 1).

It seems that these climatic elements have been effective in the climatic systematization and formation of the region, and directly and indirectly affect the growth of Ar. sieberi and Ar. aucheri in a way that can reflect the acclimation of this species in its habitat. Then a matrix of $164 \times 117$ (stations on rows and variables on columns) was formed. The kriging geostatistical method was used to convert station point data to spatial data. The kriging estimator is one of the most important unbiased linear estimators because, firstly, it is without systematic error (Davis, 1986) and secondly, its estimation variance is minimal; therefor, the Kriging method was used in this study. This feature can increase the matching of the maps extracted from factor analysis and vegetation areas of these species in studying the plant species of natural areas. The point data matrix was converted to a spatial data matrix with dimensions of $1267 * 1167$ using Surfer Ver14 software during the kriging interpolation process. This matrix covered the whole of Iran and was used as the input of principal component analysis. The principal component analysis, with the Varimax rotation, was used to reduce the number of factors and study the acclimation of $A r$. sieberi and Ar. aucheri. The factor load matrix and the factor score matrix were obtained using principal component analysis. The factor load matrix obtained from the principal components analysis on climatic variables determined the effects of each component on them, and the factor score matrix was used to map the factors in Surfer software. Then, the vegetation type map of Ar. sieberi and Ar. aucheri was prepared on a scale of 1:250,000 by field observations and recording the species points using GPS and GIS software. To record the points by GPS, the pixel size of $36 \times 36$ square kilometers was used, so that the range of each pixel was determined and the coordinates of 40 points containing these species were taken by GPS. The accuracy of the vegetation map was confirmed by the Research Institute of Forests and Rangelands. Then, the map of factors was adapted to the vegetation map, and the mean factors extracted from factor analysis in the distribution areas of different types of these species were determined. 
Table 1

Climatic elements affecting the growth of Ar. sieberi and Ar. aucheri

\begin{tabular}{|c|c|c|c|c|c|}
\hline $\begin{array}{l}\text { Sign } \\
\text { element }\end{array}$ & $\begin{array}{l}\text { Climatic } \\
\text { element }\end{array}$ & $\begin{array}{l}\text { Sign } \\
\text { element }\end{array}$ & Climatic element & $\begin{array}{l}\text { Sign } \\
\text { element }\end{array}$ & Climatic element \\
\hline V89 & $\begin{array}{l}\text { March average } \\
\text { wind speed }\end{array}$ & V46 & $\begin{array}{l}\text { Average annual relative } \\
\text { humidity }\end{array}$ & V1 & Mean minimum temperature in January \\
\hline V90 & $\begin{array}{l}\text { April average } \\
\text { wind speed }\end{array}$ & V47 & $\begin{array}{l}\text { Maximum relative } \\
\text { humidity in March }\end{array}$ & V2 & $\begin{array}{l}\text { Mean minimum temperature in } \\
\text { February }\end{array}$ \\
\hline V91 & $\begin{array}{l}\text { May average } \\
\text { wind speed }\end{array}$ & V48 & $\begin{array}{l}\text { Maximum relative } \\
\text { humidity in April }\end{array}$ & V3 & Mean minimum temperature in March \\
\hline V92 & $\begin{array}{l}\text { Jun average } \\
\text { wind speed }\end{array}$ & V49 & $\begin{array}{l}\text { Maximum relative } \\
\text { humidity in May }\end{array}$ & V4 & Mean minimum temperature in October \\
\hline V93 & $\begin{array}{l}\text { Jul average } \\
\text { wind speed }\end{array}$ & V50 & $\begin{array}{l}\text { Maximum relative } \\
\text { humidity in Jun }\end{array}$ & V5 & $\begin{array}{l}\text { Mean minimum temperature in } \\
\text { November }\end{array}$ \\
\hline V94 & $\begin{array}{l}\text { August average } \\
\text { wind speed }\end{array}$ & V51 & $\begin{array}{l}\text { Maximum relative } \\
\text { humidity in September }\end{array}$ & V6 & $\begin{array}{l}\text { Mean minimum temperature in } \\
\text { December }\end{array}$ \\
\hline V95 & $\begin{array}{l}\text { September } \\
\text { average wind } \\
\text { speed }\end{array}$ & V52 & $\begin{array}{l}\text { Maximum relative } \\
\text { humidity in October }\end{array}$ & V7 & Mean minimum of annual \\
\hline V96 & $\begin{array}{l}\text { October average } \\
\text { wind speed }\end{array}$ & V53 & $\begin{array}{l}\text { Maximum annual } \\
\text { relative humidity }\end{array}$ & V8 & $\begin{array}{l}\text { Days with a minimum temperature of } 4 \\
\text { degrees Celsius and lower January }\end{array}$ \\
\hline V97 & $\begin{array}{l}\text { November } \\
\text { average wind } \\
\text { speed }\end{array}$ & V54 & $\begin{array}{l}\text { Minimum relative } \\
\text { humidity in March }\end{array}$ & V9 & $\begin{array}{l}\text { Days with a minimum temperature of } 4 \\
\text { degrees Celsius and lower February }\end{array}$ \\
\hline V98 & $\begin{array}{l}\text { December } \\
\text { average wind } \\
\text { speed }\end{array}$ & V55 & $\begin{array}{l}\text { Minimum relative } \\
\text { humidity in April }\end{array}$ & V10 & $\begin{array}{l}\text { Days with a minimum temperature of } 4 \\
\text { degrees Celsius and lower December }\end{array}$ \\
\hline V99 & $\begin{array}{l}\text { Annual average } \\
\text { wind speed }\end{array}$ & V56 & $\begin{array}{l}\text { Minimum relative } \\
\text { humidity in May }\end{array}$ & V11 & $\begin{array}{l}\text { Days with a minimum temperature of } 4 \\
\text { degrees Celsius and lower annual }\end{array}$ \\
\hline V100 & $\begin{array}{l}\text { January cloudy } \\
\text { days }\end{array}$ & V57 & $\begin{array}{l}\text { Minimum relative } \\
\text { humidity in Jun }\end{array}$ & V12 & Number of January frost days \\
\hline V101 & $\begin{array}{l}\text { February cloudy } \\
\text { days }\end{array}$ & V58 & $\begin{array}{l}\text { Minimum relative } \\
\text { humidity in September }\end{array}$ & V13 & Number of February frost days \\
\hline V102 & $\begin{array}{l}\text { March cloudy } \\
\text { days }\end{array}$ & V59 & $\begin{array}{l}\text { Minimum relative } \\
\text { humidity in October }\end{array}$ & V14 & Number of December frost days \\
\hline V103 & $\begin{array}{l}\text { April cloudy } \\
\text { days }\end{array}$ & V60 & $\begin{array}{l}\text { Minimum annual } \\
\text { relative humidity }\end{array}$ & V15 & Number of annual frost days \\
\hline V104 & $\begin{array}{l}\text { December } \\
\text { cloudy days }\end{array}$ & V61 & $\begin{array}{l}\text { The amount of } \\
\text { precipitation in January }\end{array}$ & V16 & Absolute minimum annual temperature \\
\hline V105 & $\begin{array}{l}\text { Annual cloudy } \\
\text { days }\end{array}$ & V62 & $\begin{array}{l}\text { The amount of } \\
\text { precipitation in February }\end{array}$ & V17 & $\begin{array}{l}\text { Average maximum temperature in } \\
\text { March }\end{array}$ \\
\hline V106 & March Sunshine & V63 & $\begin{array}{l}\text { The amount of } \\
\text { precipitation in March }\end{array}$ & V18 & Average maximum temperature in April \\
\hline V107 & April Sunshine & V64 & $\begin{array}{l}\text { The amount of } \\
\text { precipitation in April }\end{array}$ & V19 & Average maximum temperature in May \\
\hline V108 & May Sunshine & V65 & $\begin{array}{l}\text { The amount of } \\
\text { precipitation in May }\end{array}$ & V20 & Average maximum temperature in Jun \\
\hline
\end{tabular}




\begin{tabular}{|c|c|c|c|c|c|}
\hline $\begin{array}{l}\text { Sign } \\
\text { element }\end{array}$ & $\begin{array}{l}\text { Climatic } \\
\text { element }\end{array}$ & $\begin{array}{l}\text { Sign } \\
\text { element }\end{array}$ & Climatic element & $\begin{array}{l}\text { Sign } \\
\text { element }\end{array}$ & Climatic element \\
\hline V109 & Jun Sunshine & V66 & $\begin{array}{l}\text { The amount of } \\
\text { precipitation in Jun }\end{array}$ & V21 & Average maximum temperature in July \\
\hline V110 & Jul Sunshine & V67 & $\begin{array}{l}\text { The amount of } \\
\text { precipitation in July }\end{array}$ & V22 & $\begin{array}{l}\text { Average maximum temperature in } \\
\text { August }\end{array}$ \\
\hline V111 & $\begin{array}{l}\text { August } \\
\text { Sunshine }\end{array}$ & V68 & $\begin{array}{l}\text { The amount of } \\
\text { precipitation in August }\end{array}$ & V23 & $\begin{array}{l}\text { Average maximum temperature in } \\
\text { September }\end{array}$ \\
\hline V112 & $\begin{array}{l}\text { September } \\
\text { Sunshine }\end{array}$ & V69 & $\begin{array}{l}\text { The amount of } \\
\text { precipitation in } \\
\text { September }\end{array}$ & V24 & $\begin{array}{l}\text { Average maximum temperature in } \\
\text { October }\end{array}$ \\
\hline V113 & $\begin{array}{l}\text { October } \\
\text { Sunshine }\end{array}$ & V70 & $\begin{array}{l}\text { The amount of } \\
\text { precipitation in October }\end{array}$ & V25 & Average annual maximum temperature \\
\hline V114 & $\begin{array}{l}\text { Annual } \\
\text { Sunshine }\end{array}$ & V71 & $\begin{array}{l}\text { The amount of } \\
\text { precipitation in } \\
\text { November }\end{array}$ & V26 & Absolute maximum annual temperature \\
\hline V115 & $\begin{array}{l}\text { Winter } \\
\text { precipitation }\end{array}$ & V72 & $\begin{array}{l}\text { The amount of } \\
\text { precipitation in } \\
\text { December }\end{array}$ & V27 & January average temperature \\
\hline V116 & $\begin{array}{l}\text { Spring } \\
\text { Precipitation }\end{array}$ & V73 & $\begin{array}{l}\text { The amount of } \\
\text { precipitation in Jun }\end{array}$ & V28 & February average temperature \\
\hline \multirow[t]{13}{*}{ V117 } & $\begin{array}{l}\text { Summer } \\
\text { precipitation }\end{array}$ & V74 & $\begin{array}{l}\text { The amount of annual } \\
\text { precipitation }\end{array}$ & V29 & March average temperature \\
\hline & & V75 & $\begin{array}{l}\text { Number of days with } \\
\text { thunderstorm in March }\end{array}$ & V30 & April average temperature \\
\hline & & V76 & $\begin{array}{l}\text { Number of days with } \\
\text { thunderstorm in April }\end{array}$ & V31 & May average temperature \\
\hline & & V77 & $\begin{array}{l}\text { Number of days with } \\
\text { thunderstorm in May }\end{array}$ & V32 & July average temperature \\
\hline & & V78 & $\begin{array}{l}\text { Number of days with } \\
\text { thunderstorm in Jun }\end{array}$ & V33 & August average temperature \\
\hline & & V79 & $\begin{array}{l}\text { Number of days with } \\
\text { thunderstorm in October }\end{array}$ & V34 & September average temperature \\
\hline & & V80 & $\begin{array}{l}\text { Number of days with } \\
\text { thunderstorm annual }\end{array}$ & V35 & October average temperature \\
\hline & & V81 & $\begin{array}{l}\text { Number of dusty days } \\
\text { in April }\end{array}$ & V36 & November average temperature \\
\hline & & V82 & $\begin{array}{l}\text { Number of dusty days } \\
\text { in May }\end{array}$ & V37 & December average temperature \\
\hline & & V83 & $\begin{array}{l}\text { Number of dusty days } \\
\text { in Jun }\end{array}$ & V38 & Annual average temperature \\
\hline & & V84 & $\begin{array}{l}\text { Number of dusty days } \\
\text { in July }\end{array}$ & V39 & Average relative humidity in March \\
\hline & & V85 & $\begin{array}{l}\text { Number of dusty days } \\
\text { in August }\end{array}$ & V40 & Average relative humidity in April \\
\hline & & V45 & $\begin{array}{l}\text { Number of dusty days } \\
\text { in September }\end{array}$ & V41 & Average relative humidity in May \\
\hline
\end{tabular}




\begin{tabular}{|llllll|}
\hline $\begin{array}{l}\text { Sign } \\
\text { element }\end{array}$ & $\begin{array}{l}\text { Climatic } \\
\text { element }\end{array}$ & $\begin{array}{l}\text { Sign } \\
\text { element }\end{array}$ & Climatic element & $\begin{array}{l}\text { Sign } \\
\text { element }\end{array}$ & Climatic element \\
\hline V86 & $\begin{array}{l}\text { Number of annual dusty } \\
\text { days }\end{array}$ & V42 & Average relative humidity in Jun \\
\hline V87 & $\begin{array}{l}\text { January average wind } \\
\text { speed }\end{array}$ & V43 & Average relative humidity in September \\
\hline V88 & $\begin{array}{l}\text { February average wind } \\
\text { speed }\end{array}$ & V44 & Average relative humidity in October \\
\hline
\end{tabular}

\section{Results}

Applying a factor analysis using the principal component method and with varimax rotation showed that more than $82 \%$ of the data variance can be explained by seven factors.

The contribution of the first factor was $37.32 \%$, the second factor was $22.54 \%$, the third factor was $7.18 \%$, the fourth factor was $6.6 \%$, the fifth factor was $4.22 \%$, and the sixth factor was $4.15 \%$ percent, and the contribution of the Eigen variance of the seventh factor was less than 1. In fact, its value was less than the value of the original variables, so they were removed from later analyzes.

Therefore, it can be said that the overall climate of the study area is affected by six factors.

Table 2 shows the degree of importance of each of these factors.

Table 2

Relative importance of factors

\begin{tabular}{|lllllll|}
\hline Factors & $\mathbf{1}$ & $\mathbf{2}$ & $\mathbf{3}$ & $\mathbf{4}$ & $\mathbf{5}$ & $\mathbf{6}$ \\
\hline Eigen values & 50.35 & 30.43 & 9.69 & 8.92 & 5.70 & 5.61 \\
\hline Relative variance percentage & 37.32 & 22.54 & 7.18 & 6.61 & 4.22 & 4.15 \\
\hline Cumulative relative variance & 37.32 & 59.86 & 67.04 & 73.65 & 77.88 & 82.03 \\
\hline
\end{tabular}

Since the purpose of factor analysis is to reduce the number of variables and convert it into several new factors, so after calculating the factor load, it was determined that a set of climatic elements including mean minimum temperature (Jan, Feb, Mar, Oct, Nov, Dec, annual), days with a minimum temperature of 4 degrees Celsius and lower (Jan, Feb, Dec, annual), number of frost day (Jan, Feb, Dec and annual), absolute minimum temperature (Annual), mean maximum temperature (Mar, April, May, Jun, Jul, Aug, Sep, Oct and annual), absolute minimum temperature (annual), mean temperature (Jan, Feb, Mar, Apr, May, Jun, Jul, Sep, Oct, Nov, Dec and annual) constituted the first factor. Moreover, since temperature factors with a positive correlation were in this group, the first factor can be called the heating temperature factor.

The second factor was the spring and summer precipitation, because the factor loads of a set of climatic variables including relative humidity (Mar, Apr, May, Jun, Sep, Oct and annual), maximum relative humidity (Mar, Apr, May, Jun, Sep, Oct and annual), minimum relative humidity (Mar, Apr, Jun, Sep, Oct and annual), amount of precipitation (May, Jun, Jul, Aug, Sep, Oct), spring precipitation and summer precipitation had the most weight on these factors.

The third factor includes the average wind speed (January, February, March, April, May, June, July, August, September, October, November, December, annual) with a positive correlation, which was named as the wind factor.

The fourth factor was introduced as the autumn-winter precipitation factor, because the factor loads of the total climatic elements of precipitation (January, February, March, April, May, November, December, and annual), winter precipitation, and autumn precipitation had the highest weight. 
The fifth factor was named dusty days because the dusty-days element (April, May, June, July, August, September, and annual) is in this group with a positive correlation.

The sixth factor includes the number of cloudy days (January, February, March, April, December, and annual) and sunny hours (March, April, May, June, July, August, September, October, and annual). This factor was named cloudiness since the cloudy days and the sunny hours are in this group with a positive and negative correlation, respectively (Table 3). 
Table 3

Factor loads of 135 climatic elements in Iran

\begin{tabular}{|c|c|c|c|c|c|c|c|c|c|c|c|c|c|c|c|}
\hline 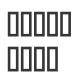 & 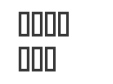 & 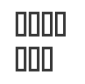 & 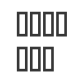 & 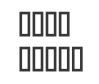 & 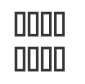 & 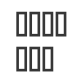 & 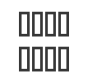 & 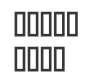 &  & 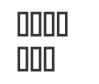 & 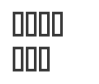 & 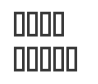 & 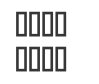 & 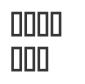 & 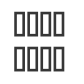 \\
\hline V1 & 0.96 & & & & & & & V69 & & 0.52 & & & & & \\
\hline V2 & 0.97 & & & & & & & V70 & & 0.54 & & & & & \\
\hline V3 & 0.96 & & & & & & & V71 & & & & 0.71 & & & \\
\hline V4 & 0.97 & & & & & & & V72 & & & & 0.91 & & & \\
\hline V5 & 0.97 & & & & & & & V73 & & & & 0.77 & & & \\
\hline V6 & 0.96 & & & & & & & V74 & & & & & & & 0.54 \\
\hline V7 & 0.98 & & & & & & & V75 & & & & & & & 0.58 \\
\hline V8 & 0.93- & & & & & & & V76 & & & & & & & 0.66 \\
\hline V9 & $0.88-$ & & & & & & & V77 & & & & & & & 0.71 \\
\hline V10 & -0.90 & & & & & & & V78 & & & & & & & 0.65 \\
\hline V11 & -0.90 & & & & & & & V79 & & & & & & & 0.80 \\
\hline V12 & -0.96 & & & & & & & V80 & & & & & 0.79 & & \\
\hline V13 & -0.95 & & & & & & & V81 & & & & & 0.78 & & \\
\hline V14 & -0.96 & & & & & & & V82 & & & & & 0.78 & & \\
\hline V15 & -0.96 & & & & & & & V83 & & & & & 0.79 & & \\
\hline V16 & 0.91 & & & & & & & V84 & & & & & 0.82 & & \\
\hline V17 & 0.89 & & & & & & & V85 & & & & & 0.84 & & \\
\hline V18 & 0.87 & & & & & & & V86 & & & & & 0.79 & & \\
\hline V19 & 0.87 & & & & & & & V87 & & & 0.95 & & & & \\
\hline V20 & 0.81 & & & & & & & V88 & & & 0.96 & & & & \\
\hline V21 & 0.73 & & & & & & & V89 & & & 0.95 & & & & \\
\hline V22 & 0.75 & & & & & & & V90 & & & 0.91 & & & & \\
\hline V23 & 0.84 & & & & & & & V91 & & & 0.79 & & & & \\
\hline V24 & 0.91 & & & & & & & V92 & & & 0.56 & & & & \\
\hline V25 & 0.88 & & & & & & & V93 & & & 0.44 & & & & \\
\hline V26 & 0.68 & & & & & & & V94 & & & 0.48 & & & & \\
\hline V27 & 0.95 & & & & & & & V95 & & & 0.67 & & & & \\
\hline V28 & 0.95 & & & & & & & V96 & & & 0.87 & & & & \\
\hline V29 & 0.93 & & & & & & & V97 & & & 0.97 & & & & \\
\hline V30 & 0.92 & & & & & & & V98 & & & 0.95 & & & & \\
\hline V31 & 0.92 & & & & & & & V99 & & & 0.85 & & & & \\
\hline V32 & 0.90 & & & & & & & V100 & & & & & & 0.52 & \\
\hline
\end{tabular}




\begin{tabular}{|c|c|c|c|c|c|c|c|c|c|c|c|c|c|c|c|}
\hline 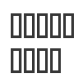 & 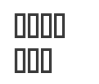 & 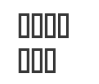 & 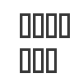 & 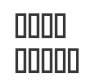 & 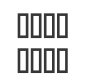 & 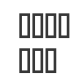 & 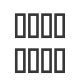 & 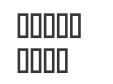 & 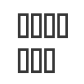 & 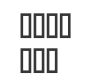 & 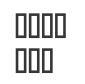 & 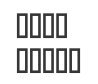 & 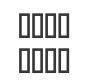 & 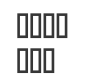 & 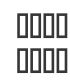 \\
\hline V33 & 0.87 & & & & & & & V101 & & & & & & 0.47 & \\
\hline V34 & 0.90 & & & & & & & V102 & & & & & & 0.52 & \\
\hline V35 & 0.95 & & & & & & & V103 & & & & & & 0.55 & \\
\hline V36 & 0.97 & & & & & & & V104 & & & & & & 0.55 & \\
\hline V37 & 0.97 & & & & & & & V105 & & & & & & 0.50 & \\
\hline V38 & 0.95 & & & & & & & V106 & & & & & & -0.54 & \\
\hline V39 & 0.96 & & & & & & & V107 & & & & & & -0.57 & \\
\hline V40 & & 0.87 & & & & & & V108 & & & & & & -0.55 & \\
\hline V41 & & 0.88 & & & & & & V109 & & & & & & -0.59 & \\
\hline V42 & & 0.93 & & & & & & V110 & & & & & & -0.57 & \\
\hline V43 & & 0.96 & & & & & & V111 & & & & & & -0.66 & \\
\hline V44 & & 0.96 & & & & & & V112 & & & & & & -0.76 & \\
\hline V45 & & 0.96 & & & & & & V113 & & & & & & -0.62 & \\
\hline V46 & & 0.96 & & & & & & V114 & & & & & & -0.70 & \\
\hline V47 & & 0.77 & & & & & & V115 & & & & 0.94 & & & \\
\hline V48 & & 0.80 & & & & & & V116 & & 0.52 & & & & & \\
\hline V49 & & 0.87 & & & & & & V117 & & 0.57 & & & & & \\
\hline V50 & & 0.96 & & & & & & & & & & & & & \\
\hline V51 & & 0.96 & & & & & & & & & & & & & \\
\hline V52 & & 0.94 & & & & & & & & & & & & & \\
\hline V53 & & 0.92 & & & & & & & & & & & & & \\
\hline V54 & & 0.91 & & & & & & & & & & & & & \\
\hline V55 & & 0.92 & & & & & & & & & & & & & \\
\hline V56 & & 0.94 & & & & & & & & & & & & & \\
\hline V57 & & 0.93 & & & & & & & & & & & & & \\
\hline V58 & & 0.92 & & & & & & & & & & & & & \\
\hline V59 & & 0.94 & & & & & & & & & & & & & \\
\hline V60 & & 0.96 & & & & & & & & & & & & & \\
\hline V61 & & & & 0.92 & & & & & & & & & & & \\
\hline V62 & & & & 0.92 & & & & & & & & & & & \\
\hline V63 & & & & 0.87 & & & & & & & & & & & \\
\hline V64 & & & & 0.60 & & & & & & & & & & & \\
\hline V65 & & 0.54 & & & & & & & & & & & & & \\
\hline
\end{tabular}




\begin{tabular}{|c|c|c|c|c|c|c|c|c|c|c|c|c|c|c|c|}
\hline 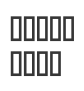 & 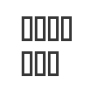 & 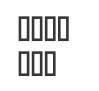 & 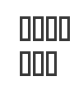 & 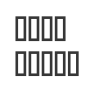 & 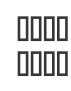 & 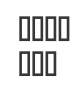 & 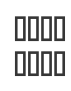 & 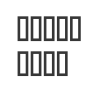 & 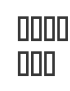 & 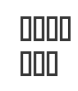 & 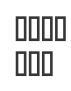 & 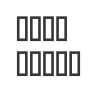 & 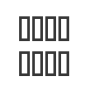 & 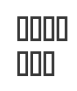 & 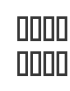 \\
\hline V66 & & 0.65 & & & & & & & & & & & & & \\
\hline V67 & & 0.64 & & & & & & & & & & & & & \\
\hline V68 & & 0.58 & & & & & & & & & & & & & \\
\hline
\end{tabular}

Figure 2 shows the spatial variations of the heating temperature factor. As is clear, the lowest and highest value of this factor is -1.6 and 2, which is observed in the northwestern region and southern regions of Bandar Abbas, respectively. As shown in this figure, moving from the western to southern regions, the amount of heating temperature increases and reaches the maximum value of this factor in the southern region, especially around Bandar Abbas. The presence of heights in the western regions of Iran reduces the temperature in these regions; however, the southern regions of Iran have the lowest altitude, and we can see the highest temperature.

The lowest score of spring and summer precipitation is -1, related to the central parts to the southeast, and the highest value is equal to 3.2, which is in the northern part of the country. Therefore, the northern regions had more spring and summer precipitation and relative humidity, while the least amount of spring and summer humidity and precipitation was observed in the central and southeastern parts of the province (Fig. 4).

Figure 5 shows the spatial variation of the third factor, wind, in the study area. The lowest score of this factor is -1.4 in all of Iran, except the eastern and southeastern regions, and the highest value is equal to 2.2, observed in all of Iran in a scattered manner.

Figure 6 shows the spatial variation of the autumn-winter precipitation. The lowest value of this factor is -1.5 , observed in the northwest corner, and the highest value is equal to 9 in the eastern part near Shahrekord.

The fifth factor is called dusty days, the highest value of which is observed near Zabol with a score of 9, and the lowest value is near Kerman and Yazd (Fig. 7). The lowest score of cloudiness factor is -1.8, related to the southern part of the country, and the highest value is 2.2 , observed in the northern part of the country (Fig. 8).

\section{Climatic characteristics of Artemisia sieberi and Artemisia aucheri}

To determine the distribution of Artemisia sieberi and Artemisia aucheri, the habitats of these two species were determined using the vegetation map prepared by the Research Institute of Forests and Rangelands and field visits (Fig. 9).

Then the vegetation map was digitized, and to investigate the effect of climatic elements on the distrbution of these two species, the factor score matrix was used. The vegetation map (Fig. 9) was adjusted with the map of variables and factor scores, the scores of each cell with these species were determined.

According to the extracted scores, the average scores of the six factors were determined and the results were listed in Table 4.

Habitats of Artemisia sieberi

The habitat area of this species in Iran is 345988.95 square kilometers $(20.99 \%)$, and this species is observed in all regions except the western half of the country.

Table 4 shows the factor scores of the seven main factors in the distribution range of this species. The scores of heating temperature, spring and summer precipitation, wind, autumn-winter precipitation, dusty and cloudy days in these areas were calculated to be $-0.21,-0.19,0.33,-0.41,-0.4$ and 0.01 , respectively.

Some climatic characteristics of Artemisia sieberi habitats are: the average annual precipitation is $158.66 \mathrm{~mm}$, the average annual temperature is $17.71^{\circ} \mathrm{C}$, the average number of frost days is 56.50 , the average wind speed is 5.46 knots (Table 5), 
and the average altitude of the areas that include this species is about 1504 meters.

Habitats of Artemisia aucheri

The habitat area of Artemisia aucheri is about $145679.55 \mathrm{~km} 2$, which occupies about $8.83 \%$ of the country's area. Table 4 shows the average factor scores for the areas where Artemisia aucheri is a companion species. The scores of heating temperature, spring and summer precipitation, wind, autumn-winter precipitation, dusty and cloudy days in these areas were calculated to be $-0.68,0.38,0.003,-0.12,-0.18$, and 0.02 , respectively.

Some climatic characteristics of these areas are: the average annual precipitation is $255 \mathrm{~mm}$, the average annual temperature is $15.27^{\circ} \mathrm{C}$, average number of frost days is 77 , the average wind speed is 5.16 knots (Table 5), and the average altitiude of the areas that include this species is about 1966 meters.

Table 4

- Mean factor scores in different regions of Artemisia sieberi and Aetemisia aucheri

\begin{tabular}{|llllllll|}
\hline $\begin{array}{l}\text { Species } \\
\text { name }\end{array}$ & $\begin{array}{l}\text { Heating } \\
\text { temperature }\end{array}$ & $\begin{array}{l}\text { Spring and summer } \\
\text { precipitation }\end{array}$ & Wind & $\begin{array}{l}\text { Autumn and winter } \\
\text { precipitation }\end{array}$ & $\begin{array}{l}\text { Dusty } \\
\text { days }\end{array}$ & cloudiness & $\begin{array}{l}\text { Mean } \\
\text { height } \\
\text { (m) }\end{array}$ \\
\hline Ar.si & -0.21 & -0.19 & 0.33 & -0.41 & -0.40 & 0.01 & 1503.95 \\
\hline Ar.au & -0.68 & 0.38 & 0.003 & -0.12 & -0.18 & -0.02 & 1966 \\
\hline
\end{tabular}


Table 5

Mean of climatic variables in different regions of Artemisia sieberi and Aetemisia aucheri

\begin{tabular}{|c|c|c|c|c|c|}
\hline Climatic element & Ar.si & Ar.au & Climatic element & Ar.si & Ar.au \\
\hline Mean minimum temperature in January & -0.70 & -2.61 & $\begin{array}{l}\text { The amount of } \\
\text { precipitation in January }\end{array}$ & 27.39 & 36.47 \\
\hline Mean minimum temperature in February & 1.69 & -0.47 & $\begin{array}{l}\text { The amount of } \\
\text { precipitation in February }\end{array}$ & 22.18 & 34.65 \\
\hline Mean minimum temperature in March & 5.81 & 3.52 & $\begin{array}{l}\text { The amount of } \\
\text { precipitation in March }\end{array}$ & 29.19 & 44.45 \\
\hline Mean minimum temperature in October & 11.36 & 8.87 & $\begin{array}{l}\text { The amount of } \\
\text { precipitation in April }\end{array}$ & 20.72 & 33.97 \\
\hline Mean minimum temperature in November & 5.34 & 3.47 & $\begin{array}{l}\text { The amount of } \\
\text { precipitation in May }\end{array}$ & 11.29 & 18.68 \\
\hline Mean minimum temperature in December & 1.15 & -0.47 & $\begin{array}{l}\text { The amount of } \\
\text { precipitation in Jun }\end{array}$ & 3.46 & 6.04 \\
\hline Mean minimum of annual & 10.83 & 8.50 & $\begin{array}{l}\text { The amount of } \\
\text { precipitation in July }\end{array}$ & 2.44 & 4.45 \\
\hline $\begin{array}{l}\text { Days with a minimum temperature of } 4 \text { degrees } \\
\text { Celsius and lower January }\end{array}$ & 8.82 & 11.69 & $\begin{array}{l}\text { The amount of } \\
\text { precipitation in August }\end{array}$ & 1.68 & 4.04 \\
\hline $\begin{array}{l}\text { Days with a minimum temperature of } 4 \text { degrees } \\
\text { Celsius and lower February }\end{array}$ & 4.56 & 7.13 & $\begin{array}{l}\text { The amount of } \\
\text { precipitation in September }\end{array}$ & 1.37 & 6.33 \\
\hline $\begin{array}{l}\text { Days with a minimum temperature of } 4 \text { degrees } \\
\text { Celsius and lower December }\end{array}$ & 5.46 & 7.46 & $\begin{array}{l}\text { The amount of } \\
\text { precipitation in October }\end{array}$ & 4.55 & 13.19 \\
\hline $\begin{array}{l}\text { Days with a minimum temperature of } 4 \text { degrees } \\
\text { Celsius and lower annual }\end{array}$ & 21.68 & 31.24 & $\begin{array}{l}\text { The amount of } \\
\text { precipitation in November }\end{array}$ & 11.08 & 22.58 \\
\hline Number of January frost days & 18.26 & 21.01 & $\begin{array}{l}\text { The amount of } \\
\text { precipitation in December }\end{array}$ & 23.19 & 33.19 \\
\hline Number of February frost days & 11.97 & 15.23 & $\begin{array}{l}\text { The amount of } \\
\text { precipitation in Jun }\end{array}$ & 158.66 & 254.85 \\
\hline Number of December frost days & 14.31 & 17.06 & $\begin{array}{l}\text { Number of days with } \\
\text { thunderstorm in March }\end{array}$ & 0.71 & 0.85 \\
\hline Number of annual frost days & 56.50 & 72.70 & $\begin{array}{l}\text { Number of days with } \\
\text { thunderstorm in April }\end{array}$ & 1.49 & 1.93 \\
\hline Average maximum temperature in March & 18.75 & 15.82 & $\begin{array}{l}\text { Number of days with } \\
\text { thunderstorm in May }\end{array}$ & 2.09 & 2.84 \\
\hline Average maximum temperature in April & 24.43 & 21.64 & $\begin{array}{l}\text { Number of days with } \\
\text { thunderstorm in Jun }\end{array}$ & 1.06 & 1.44 \\
\hline Average maximum temperature in May & 30.05 & 27.27 & $\begin{array}{l}\text { Number of days with } \\
\text { thunderstorm in October }\end{array}$ & 0.59 & 0.71 \\
\hline Average maximum temperature in Jun & 35.10 & 32.35 & $\begin{array}{l}\text { Number of days with } \\
\text { thunderstorm annual }\end{array}$ & 8.49 & 10.93 \\
\hline Average maximum temperature in July & 36.97 & 34.38 & $\begin{array}{l}\text { Number of dusty days in } \\
\text { April }\end{array}$ & 2.57 & 1.82 \\
\hline Average maximum temperature in August & 35.92 & 33.59 & $\begin{array}{l}\text { Number of dusty days in } \\
\text { May }\end{array}$ & 3.04 & 2.25 \\
\hline Average maximum temperature in September & 32.29 & 29.93 & $\begin{array}{l}\text { Number of dusty days in } \\
\text { Jun }\end{array}$ & 2.47 & 2.21 \\
\hline
\end{tabular}




\begin{tabular}{|c|c|c|c|c|c|}
\hline Climatic element & Ar.si & Ar.au & Climatic element & Ar.si & Ar.au \\
\hline Average maximum temperature in October & 26.37 & 23.99 & $\begin{array}{l}\text { Number of dusty days in } \\
\text { July }\end{array}$ & 2.84 & 2.62 \\
\hline Average annual maximum temperature & 24.80 & 22.11 & $\begin{array}{l}\text { Number of dusty days in } \\
\text { August }\end{array}$ & 1.77 & 1.83 \\
\hline January average temperature & 4.88 & 2.66 & $\begin{array}{l}\text { Number of dusty days in } \\
\text { September }\end{array}$ & 1.31 & 1.37 \\
\hline February average temperature & 7.68 & 5.12 & $\begin{array}{l}\text { Number of annual dusty } \\
\text { days }\end{array}$ & 20.65 & 16.76 \\
\hline March average temperature & 12.21 & 9.64 & $\begin{array}{l}\text { January average wind } \\
\text { speed }\end{array}$ & 4.18 & 3.90 \\
\hline April average temperature & 17.55 & 14.97 & $\begin{array}{l}\text { February average wind } \\
\text { speed }\end{array}$ & 5.45 & 4.92 \\
\hline May average temperature & 22.63 & 19.97 & March average wind speed & 6.15 & 5.66 \\
\hline July average temperature & 27.34 & 24.61 & April average wind speed & 6.29 & 5.77 \\
\hline August average temperature & 29.62 & 26.98 & May average wind speed & 6.24 & 5.79 \\
\hline September average temperature & 28.29 & 25.91 & Jun average wind speed & 6.39 & 6.23 \\
\hline October average temperature & 24.39 & 21.91 & Jul average wind speed & 6.95 & 6.83 \\
\hline November average temperature & 18.82 & 16.43 & August average wind speed & 6.38 & 6.24 \\
\hline December average temperature & 12 & 9.97 & $\begin{array}{l}\text { September average wind } \\
\text { speed }\end{array}$ & 5.32 & 5.15 \\
\hline Annual average temperature & 6.99 & 5.09 & $\begin{array}{l}\text { October average wind } \\
\text { speed }\end{array}$ & 4.36 & 4.15 \\
\hline January average temperature & 17.71 & 15.1 & $\begin{array}{l}\text { November average wind } \\
\text { speed }\end{array}$ & 3.94 & 3.68 \\
\hline Average relative humidity in March & 44.13 & 53.67 & $\begin{array}{l}\text { December average wind } \\
\text { speed }\end{array}$ & 3.80 & 3.55 \\
\hline Average relative humidity in April & 39.65 & 49.06 & Annual average wind speed & 5.46 & 5.16 \\
\hline Average relative humidity in May & 32.76 & 40.92 & January cloudy days & 5.85 & 7.10 \\
\hline Average relative humidity in Jun & 27 & 33.09 & February cloudy days & 4.81 & 6.66 \\
\hline Average relative humidity in September & 28.79 & 34.24 & March cloudy days & 6.07 & 7.99 \\
\hline Average relative humidity in October & 35.41 & 41.93 & April cloudy days & 5.41 & 6.79 \\
\hline Average annual relative humidity & 38.84 & 45.83 & December cloudy days & 5.10 & 6.37 \\
\hline Maximum relative humidity in March & 64.25 & 74.12 & Annual cloudy days & 35.03 & 46.59 \\
\hline Maximum relative humidity in April & 59.63 & 70.58 & March Sunshine & 229.72 & 206.80 \\
\hline Maximum relative humidity in May & 50.02 & 60.76 & April Sunshine & 246.39 & 229.53 \\
\hline Maximum relative humidity in Jun & 41.10 & 49.85 & May Sunshine & 304.85 & 293.22 \\
\hline Maximum relative humidity in September & 43.47 & 51.59 & Jun Sunshine & 334.84 & 329.02 \\
\hline Maximum relative humidity in October & 56.22 & 64.54 & Jul Sunshine & 335.93 & 336.33 \\
\hline Minimum relative humidity in March & 28.65 & 36.23 & August Sunshine & 336.25 & 334.01 \\
\hline
\end{tabular}




\begin{tabular}{|llllll|}
\hline Climatic element & Ar.si & Ar.au & Climatic element & Ar.si & Ar.au \\
\hline Minimum relative humidity in April & 25.16 & 32.03 & September Sunshine & 304.98 & 297.98 \\
\hline Minimum relative humidity in May & 20.87 & 26.43 & October Sunshine & 277.77 & 264.58 \\
\hline Minimum relative humidity in Jun & 17.38 & 21.33 & Annual Sunshine & 3190.66 & 3033.35 \\
\hline Minimum relative humidity in September & 18.44 & 21.24 & Winter precipitation & 78.76 & 115.58 \\
\hline Minimum relative humidity in October & 23.06 & 26.84 & Spring Precipitation & 35.48 & 58.69 \\
\hline Minimum annual relative humidity & 26.25 & 31.46 & Summer precipitation & 5.49 & 14.82 \\
\hline
\end{tabular}

\section{Discussion}

The type of climate is one of the most influential factors on the life of a region; thus, the distribution of plants and animals is closely related to the climatic conditions of each region. Therefore, knowing the type of climate of a region and the dominant elements that determine the climate of that region can help planners to gain a correct understanding of the climatic conditions of the region to carry out macro projects (Shirani et al., 2009).

In this study, the habitats of two important species, distributed widely in the rangelands of Iran, were selected. Therefore, 117 climatic variables, which were more important in the growth of Artemisia aucheri and Artemisia sieberi, were used, and the number of variables was reduced from 117 to six by factor analysis.

These six factors accounted for about $82 \%$ of the data variance, and in order of importance were heating temperature (37.32 $\%)$, spring and summer precipitation (22.54 \%), wind (7.18\%), autumn-winter precipitation (6.61\%), dusty days (4.22\%), and cloudiness days (4.15\%), respectively. In many studies conducted by $\star \star \star$, temperature, precipitation, and wind were the most important climatic factors. Hessel and et al (2003) showed that precipitation, temperature, wind speed, evaporation potential, and sunshine hours accounted for about $97 \%$ of the variance of the initial variables and separated the different regions of Ireland and Britain. Differences in other influential variables, except precipitation and temperature, can be due to several reasons, one of which is the number and type of input variables, and the other is the time intervals that can affect the amount of variance of the data.

Comparison of factor scores in Artemisia sieberi and Artemisia aucheri habitats showed that although the heating temperature factor was negative in both habitats, Artemisia sieberi habitats got a higher score for temperature as compared with Artemisia aucheri. Actually, Artemisia sieberi is distributed in warmer habitats. Attention to the average height (altitude) and annual temperature of these two habitats confirms this view, so that the average height of Artemisia sieberi habitat is 1503 meters, while it is equivalent to 1966 meters for Artemisia aucheri. Also, the average temperature in the habitats of Artemisia sieberi is equal to $17.71^{\circ} \mathrm{C}$, and it decreases to about $15.5^{\circ} \mathrm{C}$ in the habitats of Artemisia aucheri.

For the second factor (summer spring precipitation), the difference between the two habitats is quite noticeable; while the habitat score of Artemisia sieberi is negative, it is positive for Artemisia aucheri, which indicates that Artemisia aucheri needs more moisture than Artemisia sieberi.

The score of the third factor in Artemisia sieberi habitats is higher than that of Artemisia aucheri habitats. It seems that Artemisia sieberi habitats are located in lowland areas with higher temperatures, which may be due to the fact that Artemisia sieberi habitats are formed in the lowlands and along the central desert and other scattered deserts in central Iran. Besides, the significant difference between the daily and night temperature, as well as the absence of trees and low natural vegetation cover, have provided the conditions for the wind to blow.

Considering that this research was conducted in Iran and especially in the northern regions of the country, which have a precipitation of more than $1500 \mathrm{~mm}$, it makes sense for these two species to receive low score from the forth factor (autumn

Page $15 / 27$ 
winter precipitation); however, again, a lower score was obtained for Artemisia sieberi than Artemisia aucheri. The annual precipitation in the habitats of Artemisia sieberi and Artemisia aucheri is equal to 159 and 255, respectively. Therefore, Artemisia aucheri has a higher moisture requirement.

The habitats of the two species received a negative score for the fifth factor, which indicates that the habitats of these two species were distributed in areas with clear weather.

Although the sixth factor explain small changes, both species get scores around zero.

In general, the comparison of the most important climatic factors affecting the habitat of Artemisia sieberi showed that heating temperature, spring and summer precipitation, autumn-winter precipitation, and dusty days were negative in the areas that include this species. However, wind and cloudiness were positively effective in the habitat of this species.

For Artemisia aucheri, heating temperature, autumn-winter precipitation, dusty and cloudy days were negative in the areas that include this species. Therefore, the amount of spring and summer precipitation, which is the precipitation of the growing season, can affect the production of Ar.sieberi.

Ehsani et al. (2007) showed that the growing season precipitation plus the previous one as a variable in production played a major role, and there was a linear relationship between the growing season precipitation plus the previous one with production.

According to Hanson et al. (1982), moisture from the previous precipitation and the beginning of the growing season remained in the soil as stored moisture, and perennials and shrubs use the moisture stored in the growing season due to their deep roots.

In general, the autumn-winter precipitation factor had the highest effect on the presence of Ar.sieberi, so that this factor was negative in the areas where the species was present and showed a significant difference with areas lacking this species; thus, this species can grow in areas with low precipitation.

The heating temperature factor had the highest effect on the presence of Ar.aucheri, so that the amount of this factor was negative, indicating that this species prefers cold regions. Since Ar.sieberi grows in the plains and Ar.aucheri in the highlands, the heating temperature has a negative effect on Ar.aucheri. Therefore, the relatively high areas are the habitats of this plant. Hosseini et al. (2013) also reported altitude and climatic conditions as factors affecting the presence of A.aucheri. Zare Chahouki (2001), in the study of the distribution of vegetation types of Poshtkouh rangelands of Yazd province, concluded that $A$. aucheri was distributed from an altitude of 2400 meters and above on relatively sloping lands. Azarnivand et al. (2003) studied the growth characteristics of Ar.sieberi and Ar.aucheri in the rangelands of Vardavard, Garmsar, and Semnan, and the altitude above sea level was found effective in the establishment of these two species. The comparison between Ar.sieberi and Ar.aucheri showed that the amount of spring and summer precipitation and the cloudiness factor had an opposite effect in both species. Ar. sieberi is a thermophilic species distributed in the lowlands, indicating the positive effect of the cloudiness factor, while Ar. Aucheri is distributed at high altitudes and prefers sunny hours. Also, Ar.sieberi species is more resistant to low precipitation during the growing season than Ar.aucheri, indicating the positive effect of spring and summer precipitation. Artemisia species and the study of the effect of environmental factors on their distribution are of great importance in the planning and management of natural resource areas. Moreover, Artemisia is one of the most important plants in the country's rangelands. Hence, the results of this study can be applied to planning for the conservation, management, and reclamation of rangelands.

However, the relationship between plants and environmental factors is very complex and delicate, the study of which requires long-term and complete studies. Given the importance of these rangelands, proper and planned management is essential in these areas.

\section{Declarations}

Page 16/27 


\section{Ethical Approval}

- The manuscript has not been submitted to more than one journal for simultaneous consideration.

- The submitted work is original and has not been published elsewhere in any form or language

- A single study is not split up into several parts to increase the quantity of submissions and submitted to various journals or to one journal over time

\section{Consent to Participate}

All authors contributed to the study conception and design. Material preparation, data collection and analysis were performed by Morteza Khodagholi, Razieh Saboohi and Ehsan zandi Esfahani. The first draft of the manuscript was written by Morteza Khodagholi and all authors commented on previous versions of the manuscript. All authors read and approved the final manuscript.

\section{Consent to Publish}

All authors agree with the publication of an article in the Journal of Climatic Change.

\section{Funding}

This article does not have any financial support and personal expenses writers do

\section{Availability of data and materials}

All data and data analysis are available.

\section{References}

1. Akbarpouryasaghi H. 1995. Study of ecological characteristics of Artemisia aucheri in Gogan and Dasht region, Master's thesis, University of Agricultural Sciences and Natural Resources, Gorgan.

2. Alizadeh, A., Kamali, Q.A. Moosavi, F and Moosavi Bayegi, M., 2012. Climate and Climatology, Ferdowsi University of Mashhad Press.

3. Azarnivand, H., Joneydi jafari, H., Zare chahooko., M.A. Jafari, M. and Nikoo, Sh. 2009. Study of the effect of livestock grazing on carbon sequestration and nitrogen storage in rangelands with Artemisia sieberi in Semnan province. Rangeland Scientific Research Journal. 4: 590-610.

4. Azarnivand H., Jafari M., Moghaddam M.R., Jalili A., Zare Chahouki M.A. 2003.

The effects of soil characteristics and elevation on distribution of two Artemisia species (Case study: Vard avard, Garmsar and Semnan rangelands). Iranian Journal of Natural Resources. 56 (1-2): 93-100.

5. Robert G, 1991, Ecological Climate Classification, USDA Forest service, Inventory \& Monitoring Institute.

6. Chamberlain D. F and Matthews V. A $\square$ Astragalus L. In: Davis PH. (ed) Flora of turkey. Edinburgh: Edinburgh university press 3: $32-42$

7. Davis C, 1986. Statistics and Data Analysis in Geology, John Wiley \& Sons Pub., New York.

8. Faraji, A. 2005. Climate and Climatology, Nahaja Air University Press.

9. Fatemi S.S, Shahriari A, Fakhireh A, Khodagholi M, 2012. Bioclimatic evaluation of Zygophyllum atriplicoides Fisch CA Mey in Isfahan province. Journal of range management. 3: 271-258.

10. Hanson C.L., Wight J.R. Smith J.P and Smoliak S, 1982. Use of historical yield data to forecast range herbage production. Journal of Range Management, 35(5), september, pp614-616. 
11. Hosseini S.Z. Kappas M, Zare Chahouki M. A, Gerold G, Erasmi S \& Rafiei Emam A, 2013. Modelling potential habitats for Artemisia sieberi and Artemisia aucheri in Poshtkouh area, central Iran using the maximum entropy modeland geostatistics. Ecological Informatics, 18: 61-68.

12. Hossel J. E, Riding A. E, Dawson T. P, Harrison P. A, 2003. The creation and characterization of a bioclimatic classification for Britain and Ireland. Conservation 11(8): 5-13. DOI: 10.1078/1617-1381-00033

13. Jafari M, Moghadam M. R, Jalili A. and Zare chahouki M. A, 2003. The effect of soil characteristics and evolution on distribution of two Artemisia spices (Case study: Vardavard, Garmsar and Semnan). Iranian Journal of Natural Resources, 1(56): 93-100

14. Jalili, A., 2015. Ecology, evolution and biography of Artemisia L. T. Forests and Rangeland Research Institute Publications, Publication No. 458, 493 pp.

15. Khodagholi M, Mokhtari A, Montazeri M, 2015. Evaluation of climatic adaptation of oak seedlings Chaharmahal and Bakhtiari Province. Iranian Journal of Forest. 4: 446-433.

16. Khodagholi, M., Shirani, K., Yazdani, M. and Keyvan darian, A., 2007. Vegetative climate zoning of Karun watershed using multivariate statistical methods and geographic information systems. Journal of Agricultural Science. 30(4): 139-152.

17. Lashani M, Parvaneh B, Beyranvand F, 2011. Climatic zoning of Lorestan province using statistical methods to determine the optimum experimental method. Journal of Physical Geography. 1: 106-86.

18. Mozaffarian V. 1989. Study and Recognition of Iranian Artemisia, Master's Thesis, Faculty of Science, Tehran University.

19. Pakzad Z, Raeini M, Khodagholi M. 2013. Effect of climatic factors on the development of habitats of Astragalus adscendens in Isfahan province. Iranian Journal of Research in grassland and desert. 2 (1): 212-199.

20. Pineda-Martinez L. F, Carbajal N, Medina-Roldan E, 2007. Regionalization and classification of bioclimatic zones in the central-northeastern region of Mexico using principal component analysis (PCA). Atmosfera. 20(2): 133-145.

21. , A. and Karimian, A.A. 2014. The effect of exclosure on some vegetation characteristics and distribution pattern of Artemisia sieberi Besser in the central steppe regions of Iran (Case study: Nodoshan rangelands of Yazd province). Iranian Journal of Range and Desert Research. 4: 747-755.

22. Raziei T, Arasteh P.D. and Saghafian B, 2005. Annual rainfall trend in arid and semi-arid regions of Iran, ICID21st European Regional Conference, PP. 20-28.

23. Saboohi, R and Barani, H., 2016. Investigation of climatic characteristics of Astragalus gossypinus Fischer (Tragacanth species) in Isfahan province. Applied ecology. 16: 13-26.

24. - Saboohi R, Khodagholi M, 2013. Bioclimatic evaluation of species Bromus tomentellus in Isfahan province. Journal of Applied Ecology. 4: 71-57.

25. Salighe M, Barimani F, Asmylnzhad M, 2008. Climatic zoning of Sistan-Baluchistan province. Journal of Geography and Development. 12: 116-101.

26. Shirani, F., Mazidi, A. and Khodagholi, M., 2009. Climatic zoning of Yazd province with multivariate statistical methods. Quarterly Journal of Geography and Regional Development. 13: 139-157.

27. Yunus F, 2011. Delineation of Climate Divisions for Peninsular Malaysia, Geospatial World Forum, Dimensions and Directions of Geospatial Industry, Hyderabad, India. 16 P.

28. Zare Chahuki M.A, 2001. The study of relationships between some plant species with some soil properties in pastures of Poshtkuh Yazd, Master's thesis, Department of Natural Resource, Tehran University.

29. Zhou D, Khan S, Abbas A, Rana T, Zhang H, Chen Y, 2009. Climatic regionalization mapping of the Murrumbidgee Irrigation Area, Australia Progress in Natural Science, 19: 1773-1779.

\section{Figures}




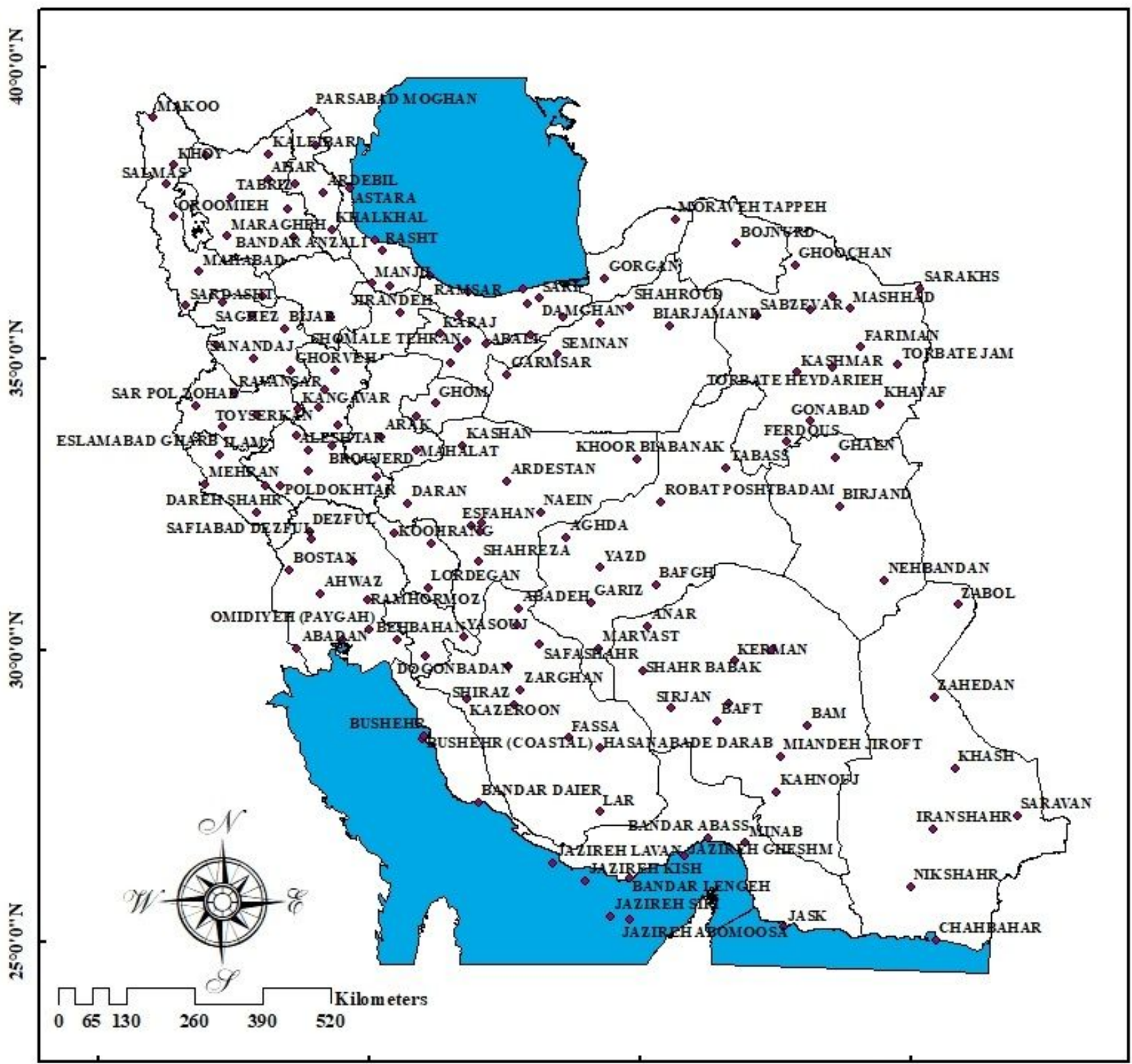

$45^{\circ} 00^{\prime \prime} \mathrm{E}$

$50^{\circ} 0^{\prime} 0^{\prime \prime} \mathrm{E}$

$55^{\circ} 0^{\prime} 0^{\prime \prime} \mathbf{E}$

$60^{\circ} 0^{\prime} 0^{\prime \prime} \mathrm{E}$

Figure 1

Location of selected meteorological stations in Iran Note: The designations employed and the presentation of the material on this map do not imply the expression of any opinion whatsoever on the part of Research Square concerning the legal status of any country, territory, city or area or of its authorities, or concerning the delimitation of its frontiers or boundaries. This map has been provided by the authors. 


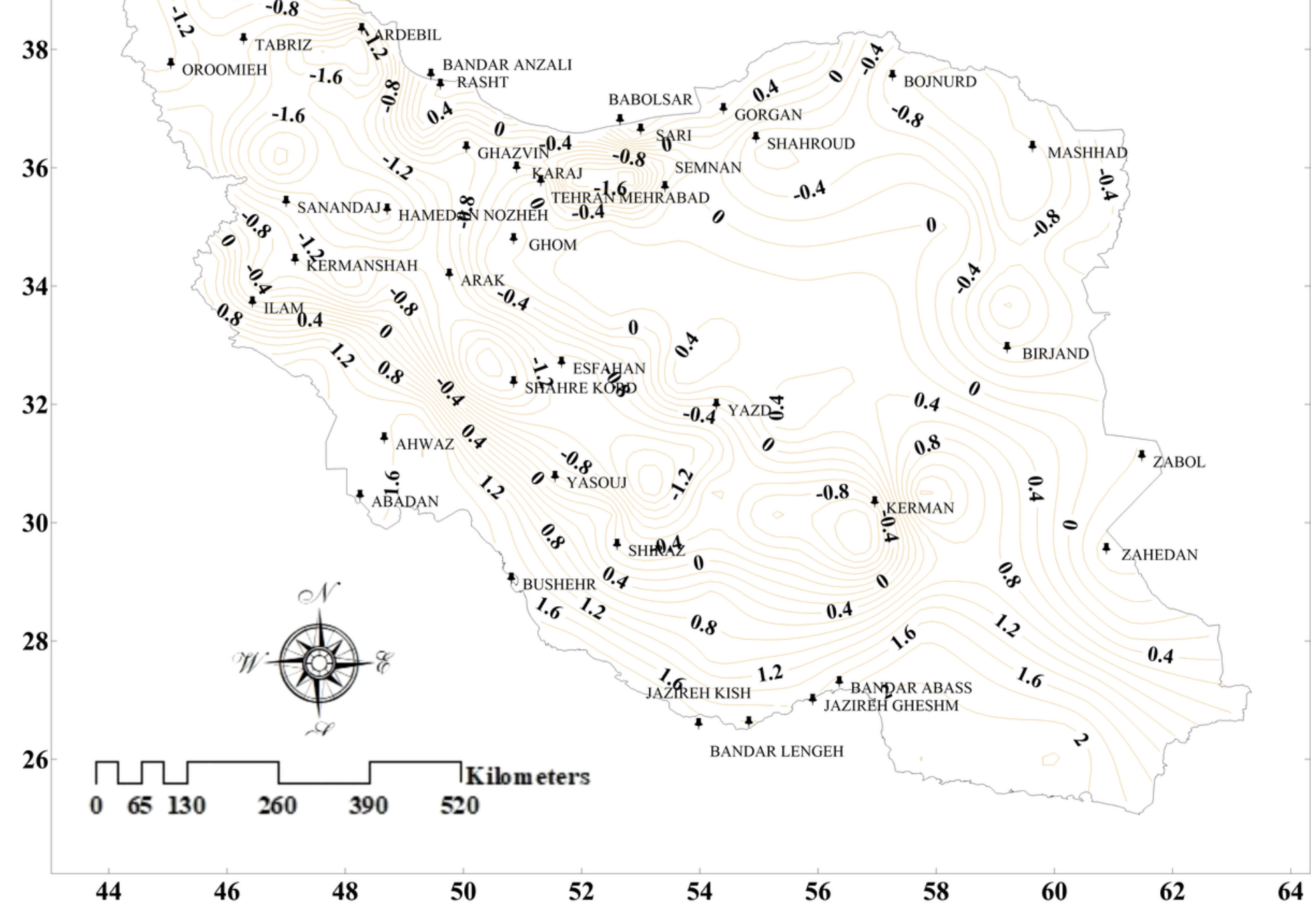

Figure 2

Distribution map of cooling-humidity temperature factor scores in Iran Note: The designations employed and the presentation of the material on this map do not imply the expression of any opinion whatsoever on the part of Research Square concerning the legal status of any country, territory, city or area or of its authorities, or concerning the delimitation of its frontiers or boundaries. This map has been provided by the authors. 


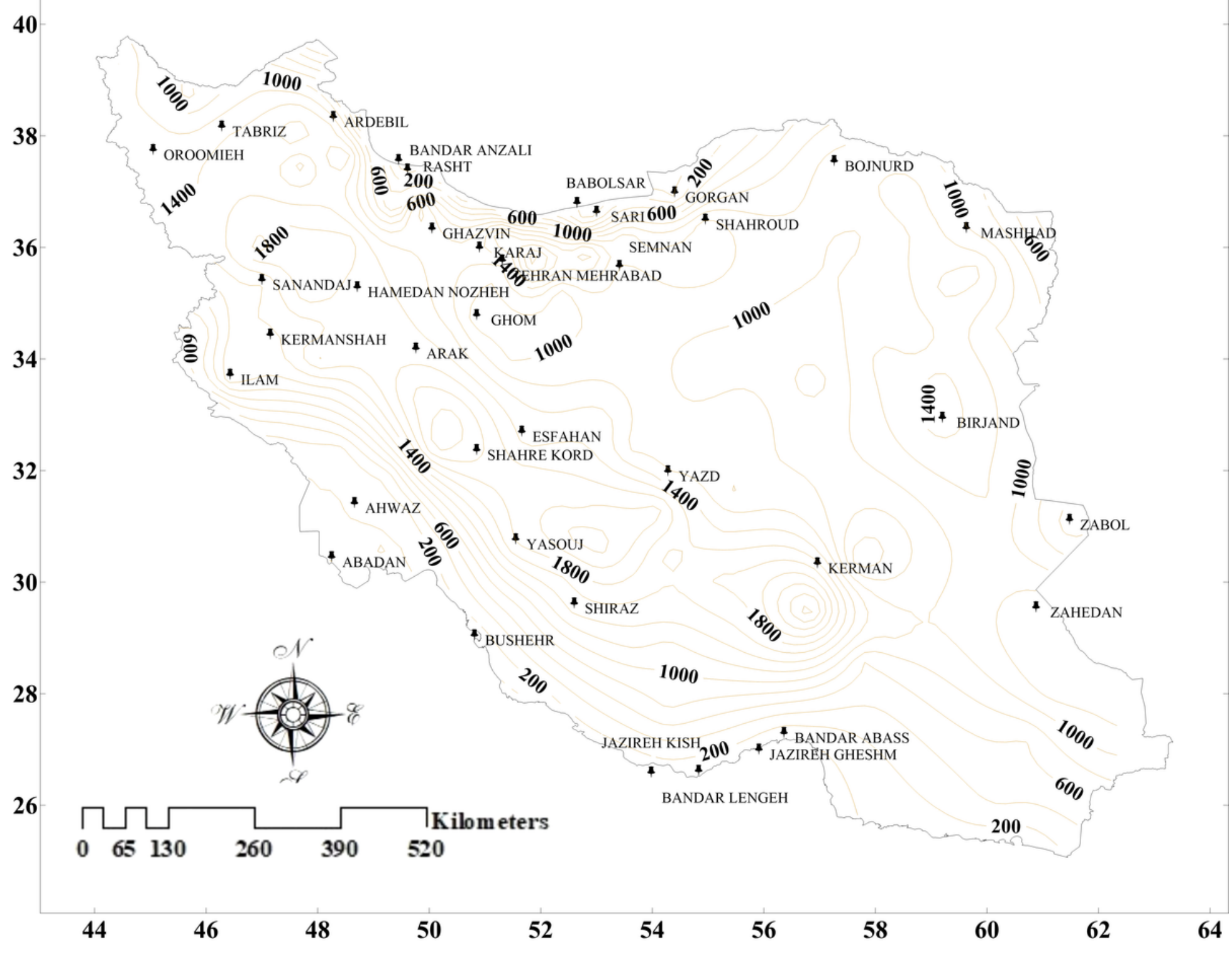

Figure 3

Elevation map in Iran Note: The designations employed and the presentation of the material on this map do not imply the expression of any opinion whatsoever on the part of Research Square concerning the legal status of any country, territory, city or area or of its authorities, or concerning the delimitation of its frontiers or boundaries. This map has been provided by the authors. 


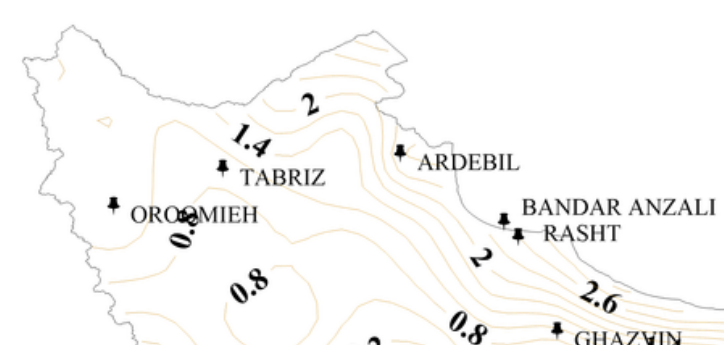

\section{6}

$0.2 \quad 0.8+{ }_{\text {GHAZYIA }}$

4 SANANDAJ4 HANếDAN NOZHEH.4

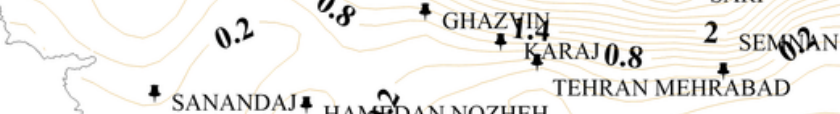

\section{4}

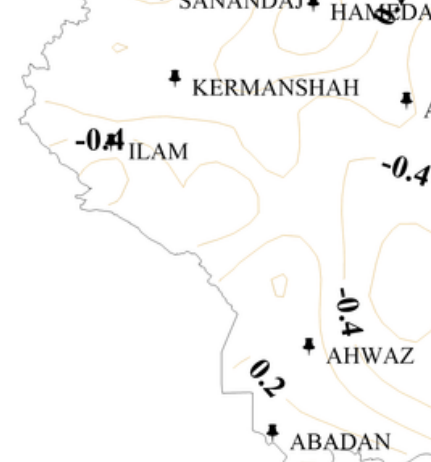

30

32

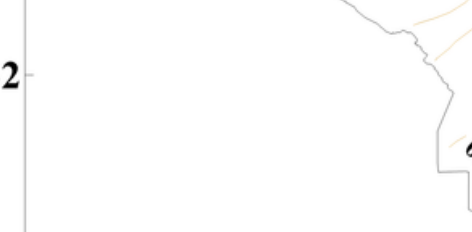

ABADAN

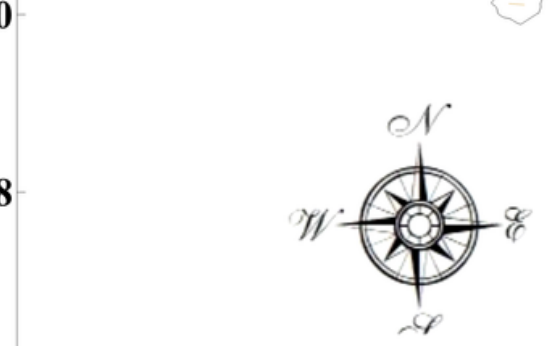

26

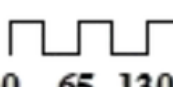

$\begin{array}{lll}0 & 65 & 130\end{array}$

YASOUJ

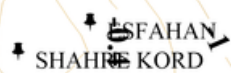

ARAK

28

\section{0 . 130}

44

46

48

50

52

54

56

58

60

62

64

Figure 4

Distribution map of summer-spring precipitation factor scores in Iran Note: The designations employed and the presentation of the material on this map do not imply the expression of any opinion whatsoever on the part of Research Square concerning the legal status of any country, territory, city or area or of its authorities, or concerning the delimitation of its frontiers or boundaries. This map has been provided by the authors. 


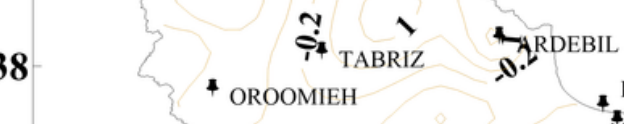

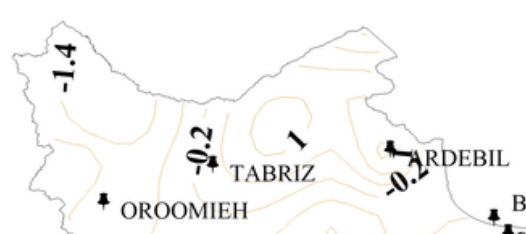

36

$-0.2$

$2-0.22 \quad 2.2$

1

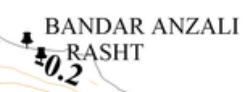

4 SANANDAJ HAMEDAN 1 TEHRAN MEHRABAB

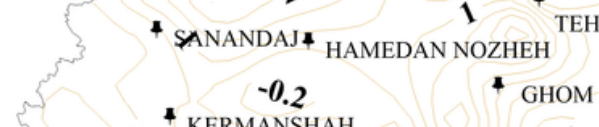

34

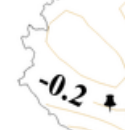

\%ั. KermanshaH

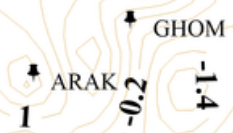

$-0.2$

32
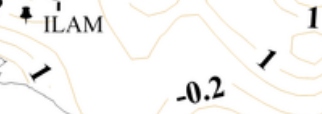

J)

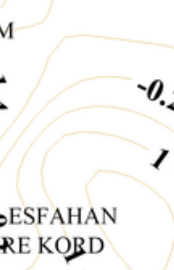

+ SHATHE KOBD
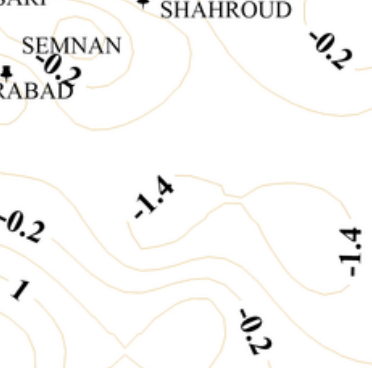

ì

4 YAZD

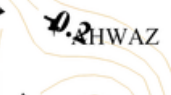

A

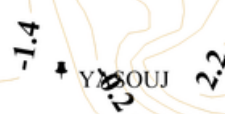

30

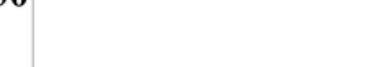

28

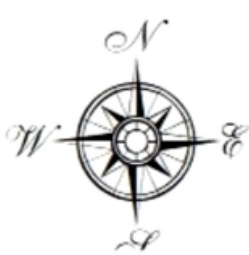

26
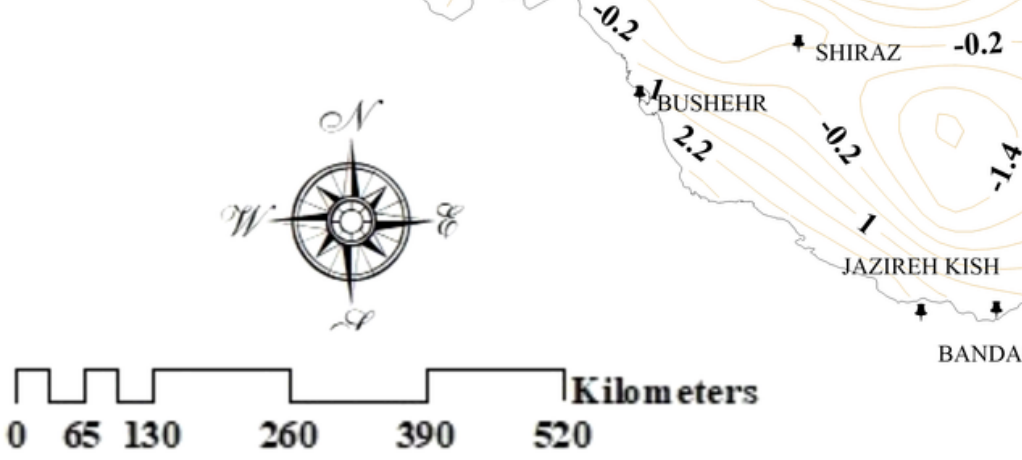

1 TeRMAN
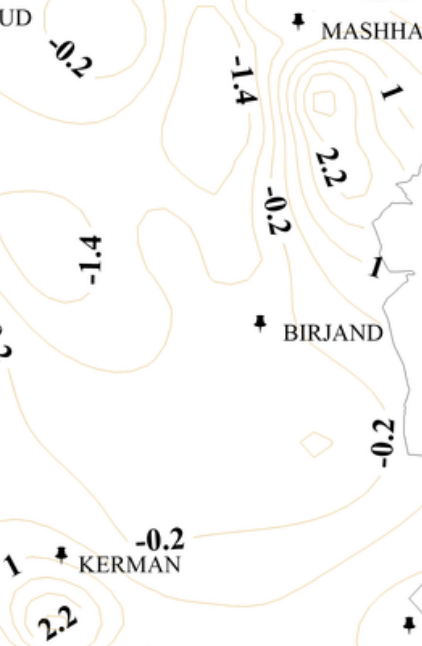

5

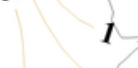

4 BIRJAND



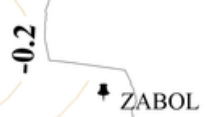

ZABOL
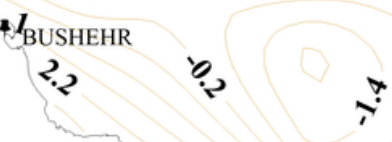

$-0.2$
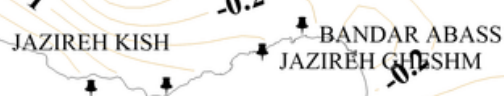

- Jaziréh go?

BANDAR LENGEH

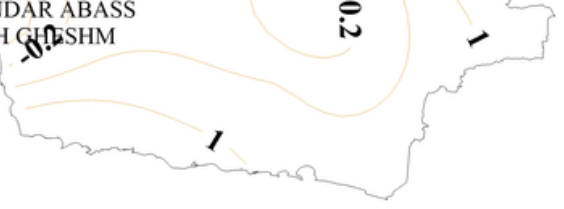

44

46

48

50

52

54

56

58

60

62

64

Figure 5

Distribution map of wind precipitation factor scores in Iran Note: The designations employed and the presentation of the material on this map do not imply the expression of any opinion whatsoever on the part of Research Square concerning the legal status of any country, territory, city or area or of its authorities, or concerning the delimitation of its frontiers or boundaries. This map has been provided by the authors. 


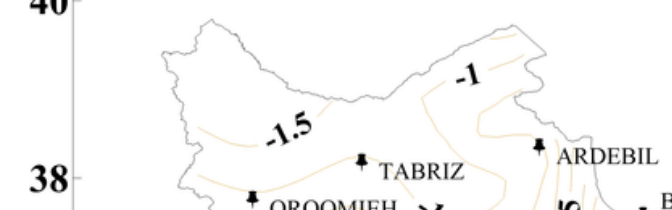

\section{6}

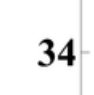

34
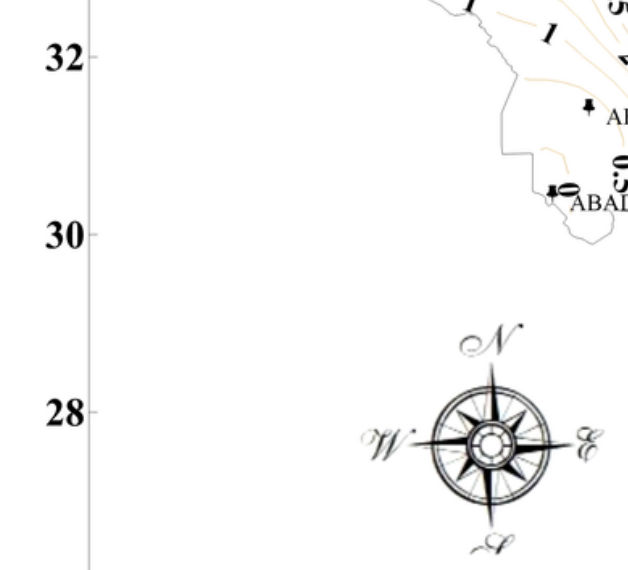
$26 \square$ Kilometers
$\begin{array}{llllll}0 & 65 & 130 & 260 & 390 & \mathbf{5 2 0}\end{array}$

$\begin{array}{lllll}44 & 46 & 48 & 50 & 52\end{array}$

525

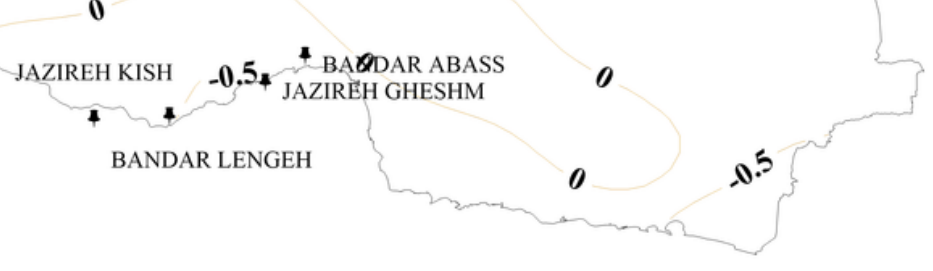

\section{Figure 6}

Distribution map winter-autumn precipitation factor scores in Iran Note: The designations employed and the presentation of the material on this map do not imply the expression of any opinion whatsoever on the part of Research Square concerning the legal status of any country, territory, city or area or of its authorities, or concerning the delimitation of its frontiers or boundaries. This map has been provided by the authors. 

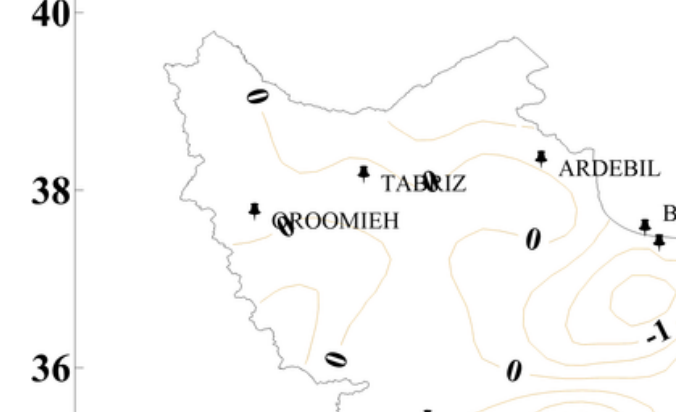

\section{4}
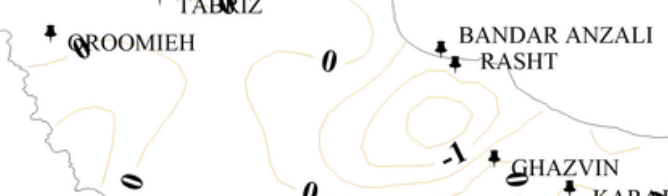

1.9 ghazVIN

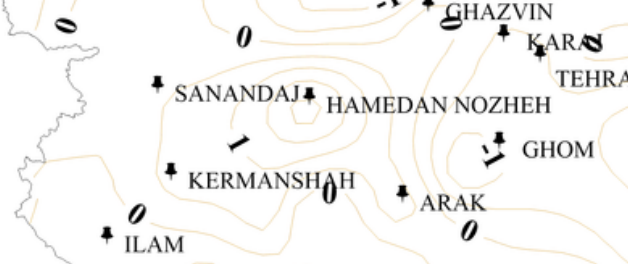

SEMNAN
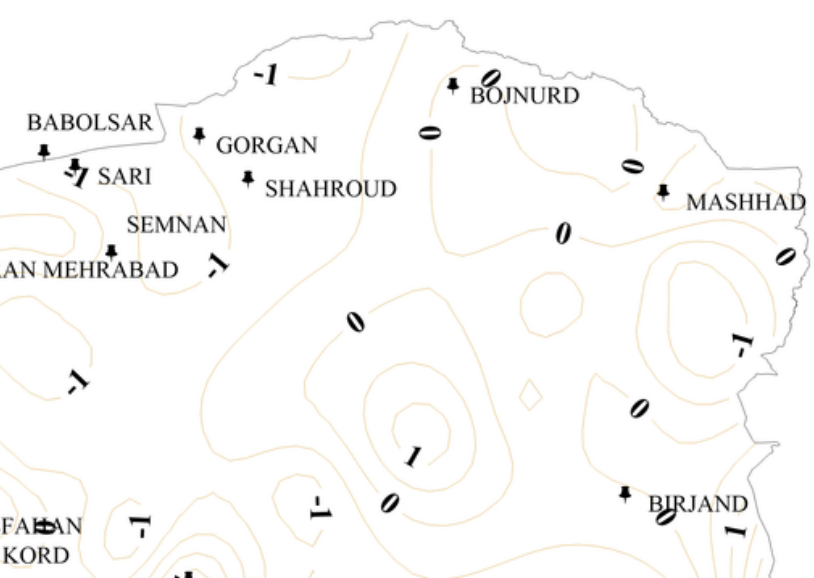

32
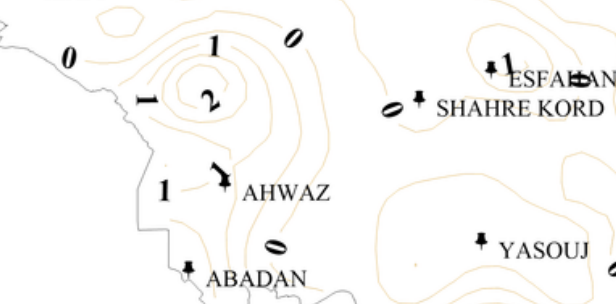

30
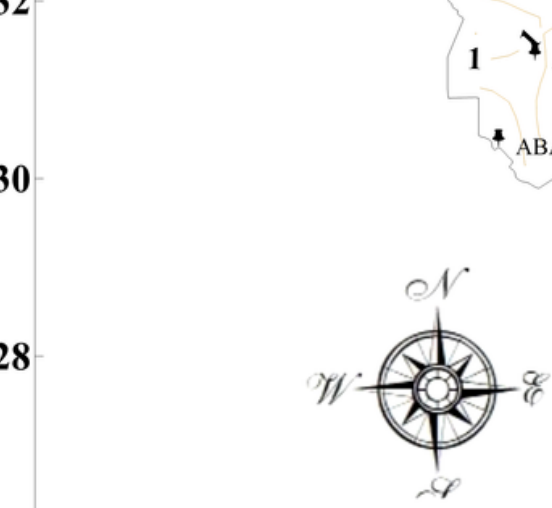

26

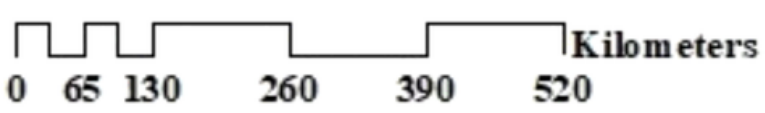

44

46

48

50

52

54

56

58

60

62

Figure 7

Distribution map of dusty days factor scores in Iran Note: The designations employed and the presentation of the material on this map do not imply the expression of any opinion whatsoever on the part of Research Square concerning the legal status of any country, territory, city or area or of its authorities, or concerning the delimitation of its frontiers or boundaries. This map has been provided by the authors. 

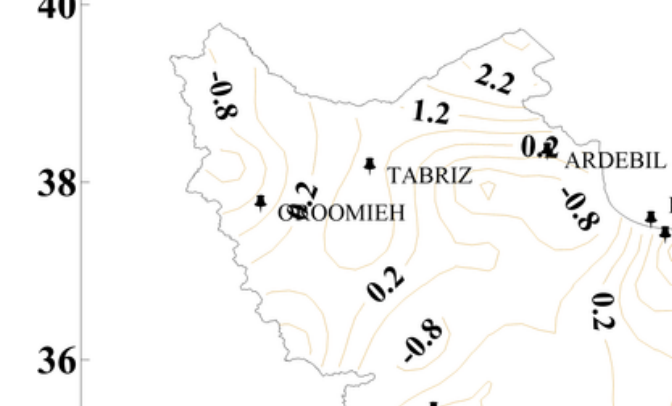

\section{4}

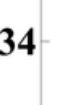

\section{2}

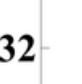

\section{0}
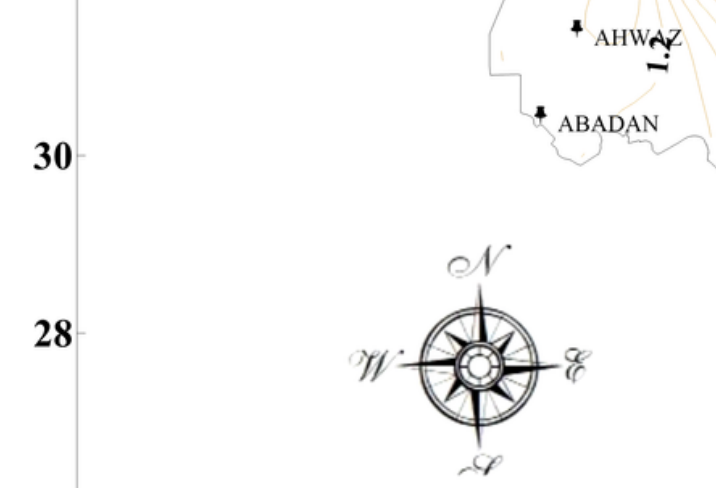

26

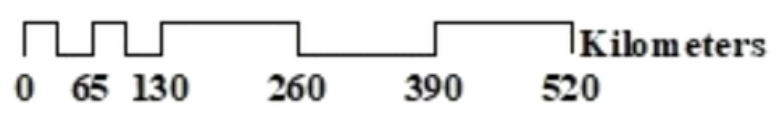
44
46
48
50

52

54

56

58

60

62

64

Figure 8

Distribution map of cloudiness factor scores in Iran Note: The designations employed and the presentation of the material on this map do not imply the expression of any opinion whatsoever on the part of Research Square concerning the legal status of any country, territory, city or area or of its authorities, or concerning the delimitation of its frontiers or boundaries. This map has been provided by the authors. 


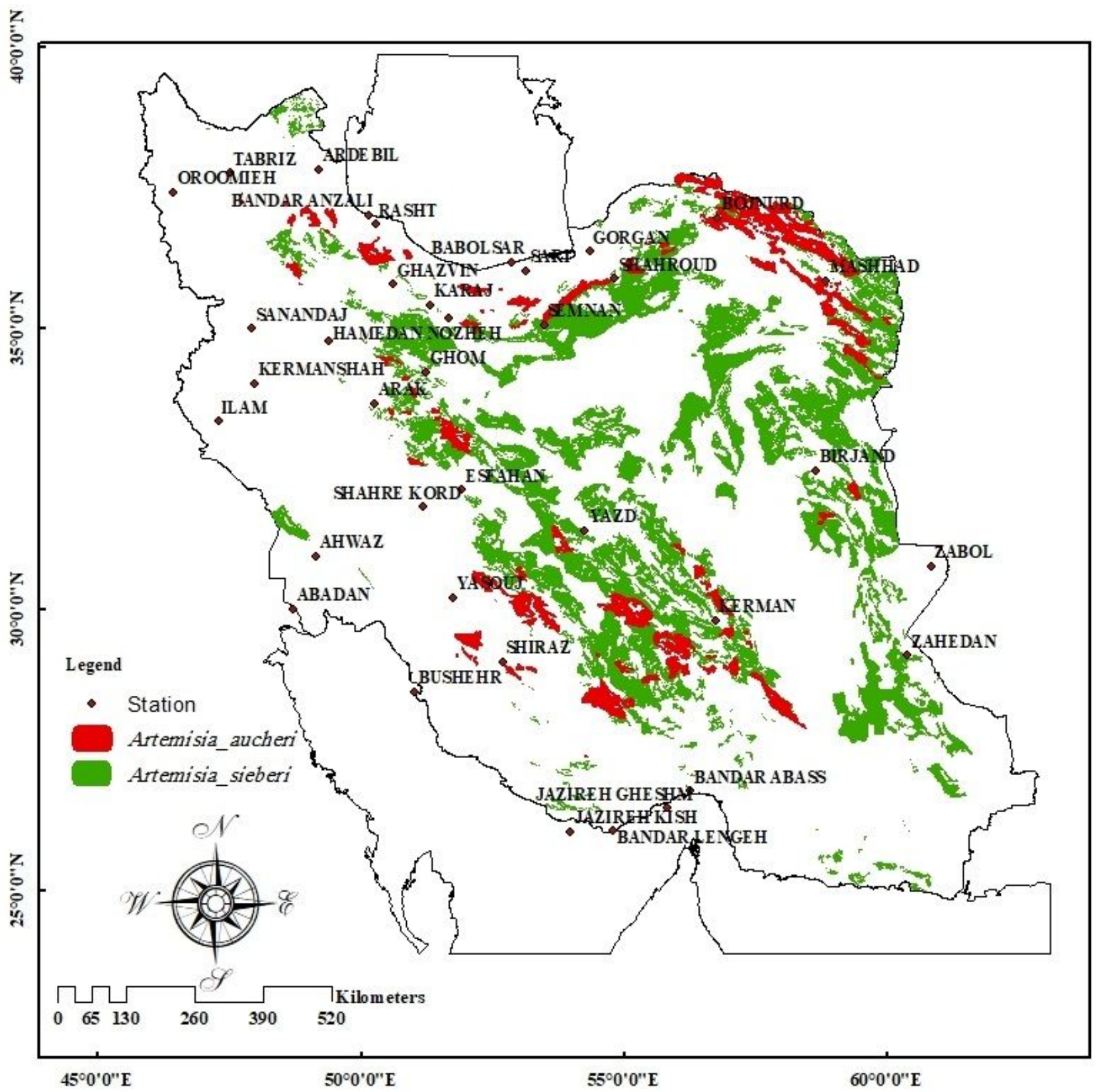

Figure 9

Distribution map of Artemisia sieberi and Aetemisia aucheri in Iran Note: The designations employed and the presentation of the material on this map do not imply the expression of any opinion whatsoever on the part of Research Square concerning the legal status of any country, territory, city or area or of its authorities, or concerning the delimitation of its frontiers or boundaries. This map has been provided by the authors. 